\title{
СУТНІСТЬ СТРАТЕГІЇ РОЗВИТКУ ФІНАНСОВО-КРЕДИТНИХ ВІДНОСИН У ВИРОБНИЦТВІ
}

\section{Рецензент - доктор економічних наук, професор І. О. Школьник}

\begin{abstract}
Сутність поняття «стратегії розвитку фінансово-кредитних відносин у виробництві» визначено як встановлену на тривалий період сукупність норм, напрямів, способів і правил функціонування в прочесі формування, розподілу та використання фінансових ресурсів, щзо забезпечить впевнений рух виробництва, його високу конкурентоздатність із метою зміинення позииії підприємства на ринку, підвищення здатності до виживання в умовах ринкової нестабільності. Розглянуто сутність понять «стратегія», «розвиток» та «фінансовокредитні відносини». Визначено значення стратегії розвитку фінансово-кредитних відносин для функиіонування виробниитва.
\end{abstract}

Ключові слова: виробництво, фінанси, кредит, фінансово-кредитні відносини, стратегія розвитку.

Постановка проблеми. Ефективність виробництва в умовах підвищення конкурентної боротьби, швидкої зміни зовнішнього середовища, невизначеності напрямів еквівалентного обміну, інфляції, росту цін на сировину й матеріали, високих процентних ставок за кредити, недостатності фінансування виробничої та наукової діяльності значно залежить від управлінської діяльності у сфері забезпечення виробництва необхідними фінансовими ресурсами, що забезпечує його рентабельність, окупність виробничих витрат i конкурентоздатність. Для забезпечення стабільності та своєчасності фінансування виробництва важливу роль відіграє розробка стратегії розвитку фінансово-кредитних відносин, яка дає змогу планувати, контролювати та регулювати інтенсивність, розміри, вартість фінансування виробництва за рахунок різних джерел, а також запобігати втратам і зменшувати ризики. Необхідність розробки стратегії розвитку фінансово-кредитних відносин у виробництві зумовлена ринковими перетвореннями й вимагає вдосконалення механізму фінансування виробництва, вдосконалення кредитної інфраструктури, як потужного важеля спрямування у виробництво значних фінансових потоків.

Аналіз останніх досліджень і публікацій, у яких започатковано розв'язання проблеми. Теоретичні та методичні проблеми визначення сутності та розробки стратегії підприємства, галузі, регіону висвітлені такими дослідниками, як I. О. Александров [13, с. 9-180], С. А. Демінський [3], В. В. Лук'янчикова [4, с. 160-164], 3. Мокринська [6, с. 282-286], А. П. Наливайко [8, с. 9-140], Г. М. Перепелиця [11, с. 64-76] та ін. Розробляються методологічні і практичні питання стратегічного управління; розкриваються основні поняття і сутність стратегічного управління, процес прийняття і вибору стратегічних рішень, умови реалізації стратегії. Проведено оцінку сучасного стану теорії стратегії підприємства та сектора економіки й викладено низку пропозицій щодо підвищення теоретичного рівня іiі розробки та здійснення; проаналізовано альтернативні системи збалансованих показників стратегії й визначено індикатори ефективного розвитку; досліджено основи стратегії економічного розвитку окремих галузей економіки та ін. Основні положення сучасних концепцій, механізмів і схем фінансування виробництва, теоретичні, методичні та практичні питання особливостей реалізації фінансово-кредитних відносин викладено у працях багатьох науковців (В. Є. Власюк $[1$, с. 8-226], О. Є. Гудзь [2, с. 5506], М. Я. Дем'яненко [14, с. 6-355 ], О. Г. Малій [5, с. 5-175], В. Опарін [10, с. 7-230] та ін.). Досліджуються процеси еволюції теоретичних напрямів становлення фінансово-кредитних відносин; організація та функціонування фінансово-кредитного механізму у різних галузях економіки; шляхи вдосконалення фінансовокредитних відносин підприємств у процесі виробництва тощо.

Мета і завдання дослідження. Метою даної статті є розкриття й обгрунтування сутності стратегіï розвитку фінансово-кредитних відносин у виробництві.

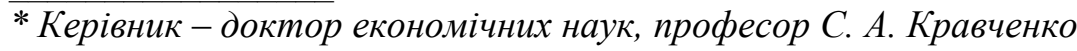


Завданнями досліджень було: визначити сутність понять «стратегія», «розвиток» та «фінансово-кредитні відносини»; обгрунтувати необхідність та особливості розробки стратегії розвитку фінансово-кредитних відносин у виробництві.

Матеріали і методи дослідження. Для написання статті використані результати досліджень провідних вчених-економістів. Досягненню цілі сприяли загальнонаукові методи: методи емпіричних досліджень, методи теоретичних досліджень (аналіз і синтез), а також низка спеціальних економічних методів (діалектичний метод пізнання, історико-економічний та класифікаційно-аналітичний).

Результати дослідження. Досить часто поняття «стратегія» використовують як синонім програми, проекту, концепції, доктрини. Економіст Г. М. Перепелиця [11, с. 64] визначає стратегію як методологію, метод розрахунку, передбачення і досягнення позитивних результатів. Науковець 3. Мокринська [6, с. 283] виділяе кілька шкіл, які висловлювали різні думки щодо трактування визначення поняття «стратегія». Серед таких шкіл варто виділити школу планування, школу становлення, школу підприємництва, пізнавальну школу, школу вивчення, школу володарювання, школу культури, проектну школу. Школа володарювання дотримується думки, що в основі формування стратегії лежать можливості влади (управління) на двох рівнях: макрорівні та глобальному рівні. Школа вивчення вважає, що творення моделі стратегії відбувається завдяки постійному процесу вивчення. Стратегія не має точного визначення, поскільки 3 постійною зміною суспільства її значення постійно доповнюється. Стратегія повсякчас знаходиться на стадії становлення. За розробками школи становлення стартовою точкою $є$ аналіз, на основі якого будується стратегія. Ця школа розвивалася у всіх напрямах; основними іiі доробками $є$ теорія і практичні приклади створення стратегічних груп, ланцюгових значень, теорії ігор, які повністю базуються на аналітичних прикладах.

Досить глибоке визначення поняття «стратегія» дав Г. Мінзберг [3]. Це визначення часто називають «п'ять П стратегії», і полягає воно в тому, що стратегія розглядається 3 п'яти точок зору, а саме: стратегія - план або орієнтир для визначення напряму розвитку; стратегія - принцип поведінки або наслідування якоїсь поведінки; стратегія - позиція, а саме розміщення конкретних товарів на конкретних ринках; стратегія перспектива, тобто основний спосіб дій організації; стратегія - прийом, здійснюваний з метою переграти конкурентів. Економіст А. П. Наливайко [8, с. 22] виділяє наступні характерні риси стратегії: процес розробки стратегії завершується не якою-небудь негайною дією, а встановленням загальних напрямів, рух за якими забезпечує зростання та укріплення позицій на ринку; визначена стратегія повинна використовуватися для розробки стратегічних проектів методом пошуків; стратегія перестає бути необхідною, як тільки реальний розвиток подій стане відповідним бажаному; при розробці стратегії неможливо передбачити всі можливості, які виникають у конкретизації цілей таі формуванні заходів; у разі появи більш точної й більш повної інформації може виникнути сумнів щодо обгрунтованості прийнятої стратегії.

У процесі дослідження встановлено, що сутність стратегії відображає еластичну, спрямовану на майбутнє модель розвитку, що включає в себе стратегічні цілі, технології, необхідні ресурси, сукупність управлінських рішень, направлених на розвиток виробництва, підвищення його конкурентоздатності та адаптації до умов ринкової нестабільності. Стратегія, як програма дій на перспективу, має носити активний характер, тобто бути спрямованою на активну побудову бажаної моделі майбутнього; стратегія формує основні етапи просування до мети.

Досить повне визначення поняття «розвиток» подає науковець С. В. Мочерний [7, с. 114], проте трактує його тільки як принцип, а крім того, не включає в зміст розвитку процеси становлення системи та іiі переходу в якісно інший стан. $\mathrm{y}$ теорії планування під розвитком розуміють відповідні зміни існуючої виробничої або економічної системи, досягнення необхідного іiї росту й оновлення окремих підсистем або їх частин. У цілому складовими визначення розвитку $€$ : кількісні та якісні зміни, процесний характер, сукупність процесів, адаптація до зовнішнього середовища, здатність протидіяти негативним впливам зовнішнього середовища, поліпшення, довготривалість, збільшення потенціалу, підвищення життєдіяльності [12, с. 78].

У процесі дослідження встановлено, що сутність розвитку відображає перехід виробничої системи під впливом факторів внутрішнього та зовнішнього середовищ до якісно й кількісно нового стану, що характеризується підвищенням здатності системи чинити опір руйнівному впливу зовнішнього середовища, а також підвищенням ефективності функціонування. Основними властивостями розвитку $є$ незворотність, спрямованість, закономірність, а також впорядкова- 
ність та активна роль внутрішніх механізмів самоорганізації.

Фінанси протягом тривалого часу ототожнювалися $з$ фінансовими відносинами, а самі фінанси розглядались як відносини. Дослідник В. М. Опарін [1, с. 7-75] розмежовує взаємопов'язані поняття фінансів і фінансових відносин. Фінансові відносини виражають сутність фінансів, як одну зі сторін виробничих (розподільчих) відносин, тоді як фінанси уособлюють не тільки відносини, а й самі фонди, як продукт цих відносин. Фінансові відносини відображають рух вартості від одного суб'єкта до іншого, характеризують обмінні, розподільні й перерозподільні процеси і проявляються у грошових потоках. На основі розвинутих фінансових відносин, що передбачають лише відносини з приводу розподілу вартості, виникають кредитні відносини, пов'язані 3 часовим та поворотним відчуженням вартості. Кредитні відносини ніколи не змінюють власника цінностей - для них характерний рух вартості на умовах повернення і платності. Формою прояву кредитних відносин є кредит, який також є формою руху позичкового капіталу. Кредит виражає економічні відносини між кредитором і позичальником, які виникають під час одержання позики, користування нею та іï повернення. Кредит, як форма руху позичкового капіталу, об'єднує в собі два процеси: 1) акумуляцію тимчасово вільних грошових коштів; 2) вкладення, або розміщення, цих коштів. В умовах розвинутого ринкового господарства кредит $є$ обов'язковим атрибутом механізму господарювання для всіх економічних суб'єктів.

У процесі дослідження встановлено, що фінансово-кредитні відносини є сукупністю економічних відносин, які пов'язані із забезпеченням виробництва необхідними фінансовими ресурсами, в тому числі на умовах повернення й платності, формування i використання фондів грошових коштів і доходів, а також контролем вказаних процесів під час фінансово-господарської діяльності з метою підвищення ефективності відтворювального процесу. Розвиток та ефективність фінансово-кредитних відносин визначається загальним станом економіки країни, i передусім розвитком виробництва.

В умовах ринкової економіки, коли простежується нестача власних коштів для фінансування виробничих процесів, а кредитні ресурси є обмеженими й важкодоступними, важливим джерелом формування фінансових ресурсів $є$ кошти іноземних інвесторів. У 2011 р. в економіку України іноземні інвестори вклали 6 млрд 473,1 млн дол. прямих інвестицій, що на 8,13 \% більше показника за 2010 р. (5 млрд 986 млн дол.). Загальний обсяг внесених із початку інвестування в економіку України прямих іноземних інвестицій (акціонерний капітал) на 31 грудня 2011 р. становив 49 млрд. 362,3 млн дол., що на 10,2 \% більше, порівняно з обсягами інвестицій на початок 2011 р., i в розрахунку на одного українця становить 1084,3 дол. Інвестиції надходили з 128 країн світу. Серед основних країн-інвесторів, на які припадає понад 83 \% загального обсягу прямих інвестицій, варто виділити: Кіпр - 12,64 млрд дол., Німеччина - 7,38 млрд дол., Нідерланди 4,82 млрд дол., Російська Федерація - 3,59 млрд дол., Австрія - 3,42 млрд дол. та ін. Заборгованість українських підприємств за кредитами i позиками, торговими кредитами та іншими зобов'язаннями перед прямими іноземними інвесторами на 31 грудня 2011 р. становила 7 млрд 960 млн дол. [9]. Отже, за останній рік простежується позитивна тенденція в інвестуванні економіки України іноземними інвесторами, що $є$ важливим джерелом фінансування діяльності вітчизняних підприємств. Інвестування виробництва України країнами-інвесторами є важливим джерелом формування фінансових ресурсів для потреб виробництва та складовою фінансово-кредитного механізму.

Сутність стратегї розвитку фінансовокредитних відносин у виробництві $\epsilon$ інтегрованою й відображає стратегічні напрями розвитку (альтернативи) і функціональні стратегії керування, і представляє собою встановлену на тривалий період сукупність норм, орієнтирів, напрямів, секторів, способів і правил у процесі формування, розподілу та використання фінансових ресурсів, що забезпечить впевнений рух виробництва, його зростання, високу конкурентоздатність, що зміцнює позиції на ринку, підвищує здатність до виживання в конкретній ситуації. Стратегія розвитку фінансово-кредитних відносин спрямована на підвищення конкурентоздатності виробництва й отримання додаткового доходу шляхом пошуку, вдосконалення та використання ефективних і рентабельних механізмів фінансування виробничої діяльності. Формування стратегіi розвитку фінансовокредитних відносин у будь-якому виробництві необхідно проводити 3 урахуванням взаємопов'язаних компонентів, а саме: суспільних потреб, внутрішніх можливостей виробництва, політичної та економічної ситуації в державі й на зовнішньому ринку. Розробка, вибір і реалізація стратегії - один із основних важелів стабільного розвитку фінансово-кредитних відносин в 
умовах ринку.

Висновки. Таким чином, у процесі дослідження встановлено, що:

1) стратегія розвитку фінансово-кредитних відносин у виробництві являє собою встановлену на тривалий період сукупність норм, напрямів, способів і правил функціонування в процесі формування, розподілу та використання фінансових ресурсів, що забезпечить впевнений рух виробництва, його високу конкурентоздатність із метою зміцнення позиції підприємства на ринку, підвищення здатності до виживання в умовах ринкової нестабільності;

\section{БІБЛІОГРАФІЯ}

1. Власюк B. С. Теоретичні і практичні аспекти функціонування фінансово-кредитної системи: [монографія] / В. Є. Власюк. - Дніпропетровськ : ДДФА, 2005. - $246 \mathrm{c}$.

2. Гудзь О. С. Фінансові ресурси сільськогосподарських підприємств: [монографія] / О. Є. Гудзь. - К. : ННЦ IАЕ, 2007. $-578 \mathrm{c.}$

3. Демінський C. А. Концептуальні засади формування стратегії страхової компанії [Електронний ресурс]: / С. А. Демінський, В. В. Родченко. - Режим доступу: http:/www.nbuv.gov.ua/ejournals/PSPE/2007-1/Rodchenko_107.htm

4. Економіка та стратегія розвитку підприємств: [колективна монографія] / За ред. В. К. Данилка. - Житомир: ЖДТУ, 2010. - 287 с.

5. Малій О. Г. Фінансово-кредитні відносини в АПК: [монографія] / О. Г. Малій. - Х. : ХНТУСГ, 2008. $-211 \mathrm{c}$.

6. Мокринська 3. Основи формування стратегії розвитку авіатранспортного сектору України / 3. Мокринська // Економічний аналіз. - 2009. Вип. 4. - С. 282-286.

7. Мочерний C. В. Методологія економічного дослідження / С. В. Мочерний. - Львів : Світ, 2001. - 416 c.

8. Наливайко А. П. Теорія стратегії підприємства.
2) особливості розробки стратегії розвитку фінансово-кредитних відносин у виробництві обумовлюються економічною й політичною ситуацією в країні, розвиненістю фінансового ринку та доступністю до кредитних коштів, станом розвитку галузей економіки, потребами виробництва у фінансових ресурсах для забезпечення виробничих процесів і підвищення конкурентоздатності й ін.

Перспективи подальших наукових досліджень у цьому напрямі пов'язані з вдосконаленням основних складових стратегії розвитку фінансовокредитних відносин у виробництві.

Сучасний стан та напрямки розвитку / А. П. Наливайко. - К. : КНЕУ, 2001. - 228 с.

9. Обсяг прямих іноземних інвестицій до України в 2011 р. зріс до 6,47 млрд. дол. [Електронний pecypc]: - Режим доступу: http://economics.unian. net/ukr/detail/120282.

10. Опарін B. Фінансова система України (теоретико-методологічний аспект): [монографія] / В. Опарін. - К. : КНЕУ, 2005. - 240 с.

11. Перепелиця Г. М. Асиметричні стратегії в гарантуванні міжнародної безпеки / Г. М. Перепелиця // Політика і час. - 2005. - № 7. - С. 6476.

12. Погорєлов Ю. С. Розвиток підприємства: поняття та види [Електронний ресурс]: / Ю.С. Погорєлов. - Режим доступу: http://www.nbuv.gov.ua/Articles/Kultnar/knp88/ knp88_75-81.pdf

13. Стратегія сталого розвитку регіону / I. О. Александров, О. В. Половян, О. Ф. Коновалов, О. В. Логачова, М. Ю. Тарасова. - Донецьк : Вид-во «Ноулідж», 2010. - 203 с.

14. Фінанси в період реформування агропромислового виробництва / М. Я. Дем'яненко, В. М. Алексійчук, А. Г. Борщ [та ін.]. - К. : IAЕ УАAH, 2002. - 645 c. 